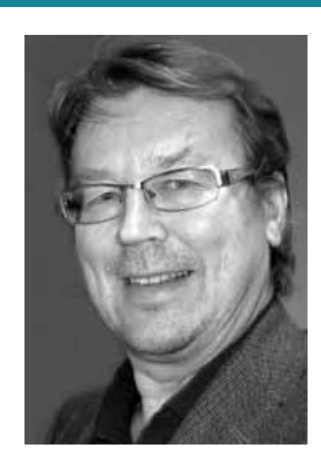

\title{
P̈̈̈̈KIRJOITUS
}

\section{YLIOPISTO JÄRJESTYKSEN KOURISSA}

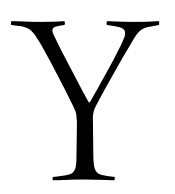

liopistolaitosta ja yliopistoissa työskenteleviä on kaulittu ja käännelty viime vuosina useaan otteeseen erilaisten uudistusten nimissä (rakenteellinen kehittäminen, laatu-, arviointi- ja seurantamekanismit, uusi palkkausjärjestelmä, tuottavuusohjelman vaikutukset, yliopistolain muutos). Tunnusomaista muutoksille on managerialisminakin tunnettu autoritaarisuus, jolla ne on suunniteltu ja toteutettu. Se on täysin vastakkainen toimintatapa yliopistoyhteisön perinteiselle kollegiaalisuudelle, joka rakentuu avoimuuden, osallisuuden ja yhteisön jäsenten tasavertaisuuden periaatteille. Kollegiaalisuuteen kuuluu kriittinen keskustelu, vapaasti esitetyt argumentit arvioidaan vertaisten keskuudessa.

Uusi yliopistolaki tuli voimaan vuoden 2010 alusta alkaen, ja tänä keväänä asiasta on ilmestynyt useita tutkimuksia. Tutkimustulokset eivät reformia ja suomalaisen yliopistolaitoksen suuntaa kiittele. Mitä uudistajien (opetus- ja kulttuuriministeriön) pitäisi tästä ajatella: korkeimman tieteellisen tutkimuksen tekijät, yliopistotutkijat, tyrmäävät uudistuksen jokseenkin täydellisesti. Miksi muuttaa yliopistolaitosta suuntaan, jota ylimmän järjen käyttäjät pitävät itse asian, eli tieteen tekemisen, kannalta järjettömänä?

TieteentekijöIden LiIton Toiseksi paras? -julkaisuksi kootut (Volanen 2012) puheenvuorot pa- nevat pohtimaan koko yliopistolaitoksen ja tieteen tulevaisuutta. Se, että kollegiaalinen periaate on pantu pois päiviltä, merkitsee sitä, että johdon valta ei perustu enää akateemisen yhteisön antamaan oikeutukseen. Jyväskylän yliopiston kasvatustieteen professori Jussi Välimaa kysyykin raportissa (s. 156), miten akateeminen yhteisö saadaan sitoutumaan päätöksiin. Ainoa vastaus on päätöksenteon vieminen mahdollisimman lähelle toimijoita sekä tieteen intresseistä lähtevän argumentaation logiikan kunnioittaminen: "Kollegiaalisuuden periaate kunnioittaa ihanteena yliopiston toiminnan luonnetta paremmin kuin nykyinen yksilöjohtajuutta korostava ja lähes narsistinen johtamisihanne."

OPETUS- JA KULTTUURIMINISTERIÖN teettämän lakiuudistuksen vaikutusten arvioinnin (OKM 2012:21) mukaan vain noin 15 prosenttia yliopistojen henkilöstöstä on sitä mieltä, että päätöksentekoprosessit ovat muuttuneet aikaisempaa selkeämmiksi, tai että henkilöstö voi nyt paremmin vaikuttaa itseään ja työtään koskeviin asioihin, tai että yliopistolainen voi vaikuttaa itseään ja työtään koskeviin asioihin, tai että hallinnolliset tehtävät vievät vähemmän aikaa kuin ennen. Yliopistojen nykyinen operatiivinen johtaminen ei tyydytä henkilöstöä lainkaan. Yliopistolaitoksen palveluksessa olevat ovat ministeriön arvioinnin mukaan lähes kokonaisuudessaan tyytymättömiä myös yli- 
opistojen henkilöstöpolitiikkaan. Asia ei olisi ministeriön kannalta niin huolestuttava, ellei henkilöstön tyytyväisyydellä ja vaikutusmahdollisuuksilla (ja niiden puuttumisella) olisi vaikutusta yliopistoissa tehtävän työn laatuun, sitoutumiseen ja ihmisten hyvinvointiin.

Paljon parempaa arviota henkilöstöltä ei saa myöskään uudistuksen vaikutus strategiseen johtamiseen ja ministeriön ohjaukseen. Valtaosa henkilöstöstä esimerkiksi katsoo, etteivät eri tason yksiköt (kuten tiedekunnat, laitokset, oppiaineet) voi riittävästi vaikuttaa yliopiston strategian sisältöön - saman aikaan kun yliopiston hallituksen asema ja strategisen johtamisen ote ovat vahvistuneet. Tämä kertoo autoritäärisestä oligarkkisuudesta. Henkilöstö ei pidä päätöksentekorakennetta yliopiston eri tasoilla (yliopisto, tiedekunnat, laitokset jne.) tarkoituksenmukaisena.

Turun Ja Helsingin YLIOPISTON kasvatussosiologien tutkimus Valta, uusi ylipistopolitiikkaa ja yliopistotyö Suomessa (Rinne, Jauhiainen, Simola, Lehto, Jauhiainen \& Laiho 2012) vahvistaa niin ikään käsitystä yliopistojen hallintokulttuurin vähenevästä demokraattisuudesta ja sakenevasta läpinäkymättömyydestä. Kontrollivallan uudet tekniikat turhauttavat erityisesti yliopiston ydintehtävää toteutettavaa tutkimus- ja opetushenkilöstöä. Lisääntyneet suunnittelu-, arviointi- ja raportointikäytännöt sekä kaikenlaisten toimintakuvausten tuottaminen vievät aikaa ydintoiminnoilta ja lisäävät tunnetta tiivistyvästä tarkkailusta. Vahvistuva yksisuuntainen kontrollointi kyynistää ja vähentää luottamusta johtajiin ja koko järjestelmään. Nämä ovat tuttuja havaintoja työnsosiologisesta tutkimuksesta vuosikymmenien takaa. Kärjistyessään autori- täärisen vallankäytön ja epäluottamuksen yhtälö on räjähdysherkkä. Niin ikään valtakunnan päättäjiä kohtaan vallitsee luottamuspula. Yliopistoväki ei luota sen enempää opetus- kuin valtiovarainministeriöön.

Tutkimusten piirtämä kuva ei ole kokonaan lohduton. Tulokset osoittavat myös sen, että tutkijat ja opettajat panevat vastaan yksisuuntaiselle, ylhäältä alaspäin suuntautuvalle vallankäytölle. Kontrollimekanismeille myös nauretaan. Seurantaraportteihin ironisoidaan rinnakkaistodellisuutta. Laatukäsikirjoihin sepitellään mitä sepitellään. Silmänpalvonta kukoistaa. Mutta se on vain terve reaktio oman tilan puolustamiseksi ja tolkullisuuden säilyttämiseksi arkipäivässä. Lattiatasolla sirkuksen pyörittäminen ruokkii kekseliäisyyttä.

OLISI LIIOITTELUA sanoa kaikkien asianosaisten olevan tyytymättömiä yliopistouudistukseen ja sen toteutukseen. Uudistuksen läpivienyt ministeri Henna Virkkunen totesi sen olevan "toiseksi paras asia, mitä yliopistoille on tapahtunut niiden perustamisen jälkeen.” Niin ikään se on linjassa elinkeinoelämän intressejä ajavan ja taloudellisen vallankäytön huipulta 'enemmistön tyranniaa' kritisoivan Björn Wahlroosin kannanottojen kanssa. Linjataanko yliopistolaitoksen tulevaisuutta sijoittaja Wahlroosin toiveiden suuntaan? Vähemmän demokratiaa! Enemmän hierarkiaa! Kovempaa johtamista! Näillä opeillahan esimerkiksi kansalaistensa ihmisoikeuksia polkeva Kiina saa houkuteltua ulkomaista rahaa ja pidettyä talouskasvun kymmenessä prosentissa. Ihmiset ovat välineitä. Paitsi ne, jotka niitä välineitä käyttävät.

Heikki Silvennoinen 